\title{
Effects of hypoxia and reoxygenation on the expression levels of the urokinase-type plasminogen activator, its inhibitor plasminogen activator inhibitor type- 1 and the urokinase-type plasminogen activator receptor in human head and neck tumour cells
}

\author{
LISA D. SPRAGUE ${ }^{1}$, HERBERT TOMASO ${ }^{3}$, KARIN MENGELE ${ }^{2}$, DANIELA SCHILLING ${ }^{1}$, \\ CHRISTINE BAYER ${ }^{1}$, PETER STADLER ${ }^{4}$, MANFRED SCHMITT ${ }^{2}$ and MICHAEL MOLLS ${ }^{1}$ \\ ${ }^{1}$ Klinik und Poliklinik für Strahlentherapie und Radiologische Onkologie, Klinikum rechts der Isar, Technische Universität \\ München; ${ }^{2}$ Klinische Forschergruppe der Frauenklinik, Klinikum rechts der Isar, Technische Universität München; \\ ${ }^{3}$ Abteilung Bakteriologie des Instituts für Mikrobiologie der Bundeswehr, München, \\ ${ }^{4}$ Strahlentherapie Mühldorf, Praxis Mühleninsel, Mühldorf, Germany
}

Received December 28, 2006; Accepted February 1, 2007

\begin{abstract}
One aim during oncological radiation therapy is to induce reoxygenation in hypoxic tumours in order to enhance radiosensitivity and ultimately increase cell death. In squamous cell carcinomas of the head and neck (SCCHN), hypoxia is considered a pivotal physiological modulator for malignant progression, whereby the plasminogen activation system is involved in overlapping functions such as the shaping of the extracellular matrix, cell proliferation and signal transduction. Since little is known about reoxygenation and the plasminogen activation system in SCCHN, three human SCCHN cell lines (BHY, FaDu, and CAL27) and a non-transformed control cell line $(\mathrm{VH} 7)$ were exposed to hypoxic $\left(<0.5 \% \mathrm{O}_{2}\right)$ conditions for up to $72 \mathrm{~h}$ and subsequently reoxygenated for $24 \mathrm{~h}$ at normoxic conditions. The mRNA expression of the urokinase-type plasminogen activator (uPA), the plasminogen activator inhibitor type-1 (PAI-1) and the urokinase-type plasminogen activator receptor (UPAR) was assessed by means of real-time semi-quantitative RT-PCR, and the protein expression was determined by immunoenzymometric quantification (ELISA). Both hypoxia and reoxygenation induced statistically significant changes in uPA, PAI-1 and uPAR mRNA and protein levels in the various cell lines investigated, showing that oxygen tension is a strong modulator of the plasminogen activation system in vitro. However, no uniform correlation pattern was found between the mRNA and protein levels
\end{abstract}

Correspondence to: Dr Lisa D. Sprague, Institut für Molekulare Pathogenese, Friedrich-Loeffler-Institut, Bundesforschungsinstitut für Tiergesundheit, Naumburgerstr. 96a, D-07743 Jena, Germany E-mail: natter13@gmx.de

Key words: urokinase-type plasminogen activator, urokinase-type plasminogen activator receptor, plasminogen activator inhibitor type-1, hypoxia, reoxygenation, head and neck tumour analysed over all three time-points $(24,48$, and $72 \mathrm{~h})$ and oxygen treatment variants $(\mathrm{N}, \mathrm{H}, \mathrm{R})$ nor according to oxygen treatment conditions over all three time-points. Changes in oxygen tension could therefore be modulating the fragile balance between the various components of the plasminogen activation system in SSCHN ultimately leading to an increased tumour matrix disruption, alterations in cell invasiveness, and the dissemination of tumour cells to distant organs.

\section{Introduction}

Tumour hypoxia is considered to be a fundamental physiological modulator of malignant progression since hypoxic tumours tend to be biologically more aggressive, resistant to radiation therapy and are therefore more likely to recur locally or metastasise $(1,2)$. Hence, one of the aims during radiation therapy is to induce the reoxygenation of hypoxic regions within the tumour in order to increase radiosensitivity and ultimately obtain a higher cell kill (3). In squamous cell carcinomas of the head and neck (SCCHN), reoxygenation during radiation therapy has been observed. However, to date, the clinical impact of reoxygenation during therapy is not entirely clear and conflicting results regarding the correlation between reoxygenation and treatment outcome have been reported (4).

The plasminogen activation system encompasses a broad spectrum of proteolytic factors involved in physiological as well as pathological processes such as fibrinolysis, tissue remodelling and tumour invasion (5). Within this system, a gene influenced by hypoxia is that of the plasminogen activator inhibitor type-1 (PAI-1) (6), a major inhibitor of the serine protease urokinase-type plasminogen activator (uPA). Upon secretion, the short-lived inhibitory activity of PAI-1 is stabilised by binding to the extracellular matrix protein, vitronectin, a cell adhesion glycoprotein involved in tissue turnover and repair. uPA is synthesized and secreted by various 
normal and tumour cells as a nearly inactive proenzyme (prouPA). Via cleavage by proteases, e.g. plasmin, its proteolytic activity increases and this enzymatically highly active form of uPA (HMW-uPA) is transferred to an even higher state of activity after binding to the specific membrane-associated receptor [urokinase-type plasminogen activator receptor (uPAR)] (CD87). This HMW-uPA then converts the plasma proenzyme plasminogen to plasmin, which can either directly degrade extracellular matrix components or act indirectly by activating pro-matrix metalloproteinases (MMPs), thus facilitating cell spread. The inhibitor PAI-1 interferes with that process by interacting with and thereby inactivating the cell membrane-associated uPAR-uPA complex. As a result, the newly formed uPAR/-uPA/-PAI-1 complex is internalised by the cell, thereby initiating signal transduction and cell proliferation (7). Thus, PAI-1 not only functions as a fibrinolytic inhibitor (8) but also plays an important role in signal transduction, cell adherence and cell migration (9), both under normal and malignant conditions, including tumour invasion and metastasis (10).

Hypoxia (the state of low oxygen supply), which is a potent inducer of angiogenesis, also promotes tumour growth, invasion and metastasis. Within this context, the arising migration of endothelial cells necessitates the proteolysis of the extracellular matrix, which is achieved by significantly up-regulating uPA and uPAR expression. However, the response of the members of the plasminogen activation system to reduced oxygen availability is not uniform. For instance, the ex vivo cultivation of human trophoblasts, human liver-derived cells or bovine endothelial cells under low oxygen induces the upregulation of PAI-1 mRNA $(6,11,12)$ whereas decreased PAI-1 mRNA levels are a feature of human corneal epithelial cells kept under hypoxic conditions (13). Likewise, with regard to uPA, Ito et al (14) observed elevated mRNA levels in the ischemic cerebral cortex of rats, while decreased uPA mRNA levels were seen in hypoxic murine lung tissue (15) and steady state uPA mRNA levels in hypoxic human microvascular endothelial cells (16). For UPAR mRNA expression after exposure to hypoxia, however, concordant results were reported: Hypoxia induces a significant upregulation of UPAR mRNA in human melanoma cells $(17,18)$, in human vascular endothelial cells (16) and in human breast carcinoma cells $(19,20)$.

A highly significant correlation of uPA, PAI-1 and UPAR expression levels with poor clinical outcome has been demonstrated by analysing tumour tissues obtained from patients afflicted with different types of solid malignant tumours, including those of the breast, gastrointestinal and genitourological tract, the lung, liver and brain as well as those of the oral cavity (21-25). Within this scenario, hypoxia and the proteolytic factors UPA, PAI-1 and UPAR are known to influence disease outcome negatively, as the impact of reoxygenation during cancer progression is still not clear.

The objective of this study was to elucidate the effects of hypoxia and reoxygenation on UPA, PAI-1 and UPAR mRNA and protein expression in a standardised in vitro environment. We therefore exposed cell lines deriving from SCCHN to hypoxia and subsequent reoxygenation and assessed the mRNA expression of UPA, PAI-1 and UPAR by means of real time semi-quantitative RT-PCR and the protein expression with immunoenzymometric quantification (ELISA).

\section{Materials and methods}

Cultivation of cells under normoxic and hypoxic conditions. The human adherently growing head and neck tumour cell lines BHY (ACC 404) and CAL27 (ACC 446) were obtained from the German Collection of Microorganisms and Cell Cultures (DSMZ, Braunschweig, Germany). The head and neck tumour cell line, FaDu (ATCC HTB-43), and the human foreskin cell line, VH-7, were kindly provided by M. Baumann (Dresden) and P. Boucamp (Heidelberg), respectively. Plastic ware for cell cultivation was obtained from TPP (Biochrom AG, Berlin, Germany). The cells were seeded onto cell culture dishes $(10 \mathrm{~cm} \varnothing)$ at a density of $5 \times 10^{4} / \mathrm{ml}$. All cell lines were cultivated in a humidified atmosphere of $95 \%$ air and $5 \%$ $\mathrm{CO}_{2}$ at $37^{\circ} \mathrm{C}$ in Dulbecco's modified Eagle's medium (DMEM; $4500 \mathrm{mg} / \mathrm{l}$ D-Glucose, $25 \mathrm{mM}$ HEPES, w/o sodium pyruvate; Invitrogen, Karlsruhe, Germany) supplemented with $10 \%$ foetal calf serum (Biochrom AG). The cells from passages 10 to 25 were used for the experiments. After 72-h cultivation under standard normoxic conditions, the medium was replaced with fresh DMEM and the dishes to be exposed to hypoxia were placed into airtight aluminium chambers (chamber A, $24 \mathrm{~h}$; chamber B, $48 \mathrm{~h}$; chamber C, $72 \mathrm{~h}$ ) connected via a tube system to a vacuum pump and an $\mathrm{N}_{2}$ gas cylinder. In order to obtain hypoxic conditions, oxygen was evacuated and displaced by $\mathrm{N}_{2}(99.9 \%)$ inflow. Gas evacuation and inflow $(-0.3 /+1.3$ bar $)$ were stop-cock controlled and the inner chamber pressure was monitored with a barometer. In order to increase gas exchange, the chambers were placed in a shaking water bath $\left(37^{\circ} \mathrm{C} ; 45 \mathrm{rpm}\right)$. Gas exchange was performed every $2 \mathrm{~min}$ for $22 \mathrm{~min}$ in total and resulted in final oxygen concentrations in the medium of $\sim 0.33 \%( \pm 0.18)$ as confirmed by polarographic needle electrode measurements using a $\mathrm{pO}_{2}$ histograph (Sigma-Eppendorf $\mathrm{pO}_{2}$ Histograph, Hamburg, Germany). The hypoxic chambers A, B and C were subsequently placed in a $37^{\circ} \mathrm{C}$ incubator for $24 \mathrm{~h}$ (short), $48 \mathrm{~h}$ (intermediate) or $72 \mathrm{~h}$ (long), respectively. Normoxic control cells were concurrently maintained under standard conditions. After 24-, 48- and 72-h hypoxic exposure, a subset of cells was allowed to reoxygenate for $24 \mathrm{~h}$ under standard conditions.

Isolation of mRNA from cell lines and cDNA synthesis. Total RNA of adherently growing cells was extracted using the RNeasy Mini Kit (Qiagen, Hilden, Germany) and subsequently transcribed (TaqMan Reverse Transcription Reagents; Applied Biosystems, Applera Deutschland GmbH, Darmstadt, Germany), both according to the manufacturer's instructions. One reverse transcription reaction contained $3.5 \mu 1$ total RNA in RNase-free water, $0.25 \mu 1$ Multiscribe Reverse Transcriptase $(50 \mathrm{U} / \mu 1)$, and $0.2 \mu 1 \mathrm{RNase}$ inhibitor $(20 \mathrm{U} / \mu \mathrm{l})$ to which $1 \mu 1$ 10X RT-buffer $(500 \mathrm{mM} \mathrm{KCl,} 100 \mathrm{mM}$ Tris$\mathrm{HCl}, \mathrm{pH} 8.3), 2.2 \mu 125 \mathrm{mM} \mathrm{MgCl}_{2}, 2 \mu \mathrm{l}$ dNTP mixture (2.5 mM each dATP, dCTP, dGTP, dTTP) and $0.5 \mu 1$ random hexamers $(50 \mu \mathrm{M})$, were added. Subsequently, the reaction mixtures were incubated for $10 \mathrm{~min}$ at $25^{\circ} \mathrm{C}$ to anneal the hexanucleotides. cDNA synthesis was performed 
Table I. List of used primers and probes for real time RT-PCR.

\begin{tabular}{|c|c|c|c|}
\hline $\begin{array}{l}\text { Gene } \\
\text { (human) }\end{array}$ & Oligonucleotide primer and probe sequence $5^{\prime}--3^{\prime}$ & $\begin{array}{l}\text { Fragment } \\
\text { size (bp) }\end{array}$ & $\begin{array}{c}\text { GenBank } \\
\text { accession no }\end{array}$ \\
\hline uPA & $\begin{array}{l}\text { F 5'-gcttgctcaccacaacgaca-3' } \\
\text { R 5'-ttcagctgctccggatagagata-3' } \\
\text { T 5'-FAM-aagatccgttccaaggagggcaggt-TAMRA-3' }\end{array}$ & 192 & NM_002658 \\
\hline PAI-1 & $\begin{array}{l}\text { F 5'-ctcctggttctgcccaagtt-3' } \\
\text { R 5'-tcgtgaagtcagcctgaaac-3' } \\
\text { T 5'-FAM-aagtcgacctcaggaagccctagagaga-TAMRA-3' }\end{array}$ & 109 & NM_000602 \\
\hline uPAR & $\begin{array}{l}\text { F 5'-agaatggccgccagtgtta-3' } \\
\text { R 5'-ggttgcacagcctcttaccata-3' } \\
\text { T 5'- FAM-ctttggtttttcggttcgtgagtgcc-TAMRA-3' }\end{array}$ & 164 & NM_002659 \\
\hline 28S rRNA & $\begin{array}{l}\text { F 5'-ttgaaaatccgggggagag-3' } \\
\text { R 5'-acattgttccaacatgccag-3' } \\
\text { T 5'-FAM-tcaccttgggagacctgctgcggat-TAMRA-3' }\end{array}$ & 99 & M11167 \\
\hline
\end{tabular}

uPA, urokinase-type plasminogen activator; PAI-1, plasminogen activator inhibitor type-1; uPAR, urokinase-type plasminogen activator receptor

for 30 min at $48^{\circ} \mathrm{C}$, followed by an enzyme inactivation step for $5 \mathrm{~min}$ at $95^{\circ} \mathrm{C}$. cDNA was stored at $-20^{\circ} \mathrm{C}$ until further use.

Real time semi-quantitative RT-PCR ( $R R T-P C R)$. Primers and probes were designed based on alignment studies using the BLAST program and sequence database of the National Centre for Biotechnology Information. The nucleotide sequences of the primers and probes used for the analysis of uPA, PAI-1, uPAR and 28S rRNA with their corresponding accession numbers are listed in Table I. Primers and probes were designed in cooperation with and obtained from TIB MOLBIOL (Berlin, Germany). For the determination of relative expression levels, $5^{\prime}$ nuclease real-time PCR were run on the ABI Prism $7000^{\text {TM }}$ sequence detection system (Applied Biosystems, Foster City, CA, USA). The $25 \mu \mathrm{l}$ reaction mixture consisted of $12.5 \mu 12 \mathrm{X}$ TaqMan $^{\text {TM }}$ Universal Master Mix (Applied Biosystems, Germany) containing dUNTPs, $\mathrm{MgCl}_{2}$, reaction buffer and AmpliTaq Gold DNA polymerase, $0.5 \mu 1$ of each primer $\left(10 \mathrm{pmol} \mu \mathrm{l}^{-1}\right)$ and $0.5 \mu \mathrm{l}$ of the TaqManTM probe $\left(10 \mathrm{pmol} \mu \mathrm{1}^{-1}\right)$. Cycling was started with a 10 min denaturation step at $95^{\circ} \mathrm{C}$ followed by 45 cycles with $15 \mathrm{sec}$ denaturation at $95^{\circ} \mathrm{C}$, and $1 \mathrm{~min}$ for annealing at $60^{\circ} \mathrm{C}$. For each examined gene, 4 to 5 individual experiments were carried out per cell line. Each reaction was done in triplicate.

Using these quantitative methods requires that the PCR efficiencies of all the genes are similar and $\geq 95 \%$. Efficiency was determined by means of a standard curve for each gene generated by serial dilutions of the cDNA. For this purpose, the initial cDNA concentration of $100 \mathrm{ng} / \mu \mathrm{l}$ was serially diluted 10-fold for the real-time PCR assay according to the standard protocol from Applied Biosystems (Fig. 1). The PCR efficiency (E) was calculated by the formula: $\mathrm{E}=10^{(1 / \text {-slope })}-1$, and ranged from $96-99 \%$ for the different assays. A slope of $-3.3( \pm 0.1)$ is equivalent to $100 \%$ PCR efficiency.

PAI-1, uPA, and UPAR ELISA. UPA, PAI-1 and UPAR proteins associated with and secreted by the cell lines were measured by ELISA (uPA, Imubind No. 894; PAI-1, Imubind No. 821; uPAR, Imubind No. 893; American Diagnostica Inc., Stamford, CT, USA) as described previously (26). Briefly, after the removal of the cell supernatant aliquots, the cells were rinsed twice with ice-cold PBS and lysed in $900 \mu 1$ buffer containing $0.05 \mathrm{M}$ Tris/ $\mathrm{HCl}, \mathrm{pH} 8.5,0.1 \mathrm{M} \mathrm{NaCl}$, $10 \mathrm{mM}$ EDTA, $0.5 \%$ Tween-20 and $0.1 \%$ Triton X-100 (all chemicals from Sigma-Aldrich, Taufkirchen, Germany). Cell lysates were rotated for $24 \mathrm{~h}$ at $4^{\circ} \mathrm{C}$, spun at $15,000 \times \mathrm{g}$ for $20 \mathrm{~min}$ at $4^{\circ} \mathrm{C}$ and the resulting cell extracts were stored at $-20^{\circ} \mathrm{C}$ until further use. The protein concentration of the detergent extracts was determined with the BCA protein assay kit (Pierce, Perbio Science, Bonn, Germany) using bovine serum albumin as the standard. All measurements were performed in duplicate. UPA, PAI-1 and UPAR protein values contained in the cell lysates and the culture supernatants are expressed as ng analyte/mg protein in the cellular detergent extract.

Analysis of gene expression using the 2- $\triangle \Delta C T$ method. Data analyses were performed with the ABI PRISM ${ }^{\mathrm{TM}}$ sequence detection software package (version 2.1; Applied Biosystems, USA). The mean target gene mRNA expression level for the three mRNA measurements was determined and the 2- $\triangle \triangle \mathrm{CT}$ method was used to calculate the relative changes in gene expression (27). For the samples exposed to hypoxia (H) and to the subsequent 24-h reoxygenation period $(\mathrm{R})$, the evaluation of $2-{ }^{-\triangle C T}$ shows the fold changes in gene expression relative to the untreated control (24-h N), i.e. $\Delta \Delta \mathrm{C}_{\mathrm{T}}=\left\{\left[\mathrm{C}_{\mathrm{T}}\right.\right.$ (sample) $-\mathrm{C}_{\mathrm{T}}$ $28 \mathrm{~S}$ rRNA (sample)] - $\left[\mathrm{C}_{\mathrm{T}}\right.$ (calibrator) $-\mathrm{C}_{\mathrm{T}} 28 \mathrm{~S}$ rRNA 


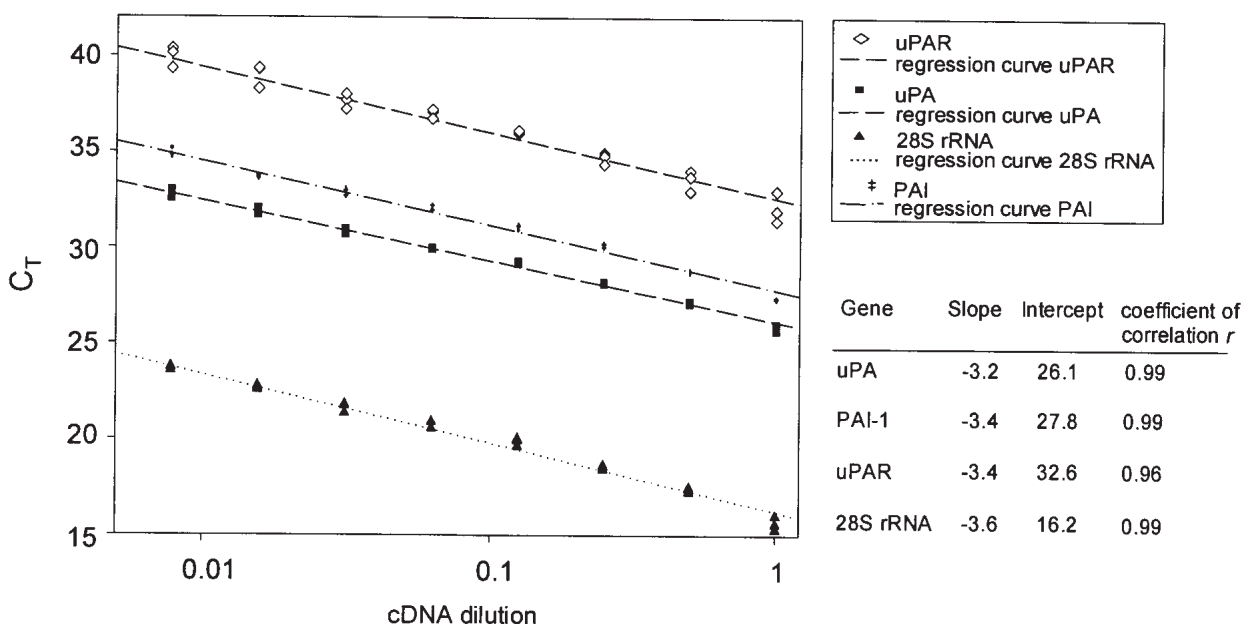

Figure 1. Regression curves for 28S rRNA, the urokinase-type plasminogen activator, plasminogen activator inhibitor type-1 and the urokinase-type plasminogen activator receptor. The initial cDNA concentration of $100 \mathrm{ng} / \mu 1$ was serially diluted 10 -fold for the real-time RT-PCR assay according to the standard protocol from Applied Biosystems. The PCR efficiency (E) was calculated by the formula: $E=10^{(1 /-s l o p e)}-1$, and ranged from $96-99 \%$ for the different assays. A slope of $-3.3( \pm 0.1)$ is equivalent to $100 \%$ PCR efficiency.

(calibrator)]\}. The results of the real time PCR are shown as $\mathrm{C}_{\mathrm{T}}$ values, where $\mathrm{C}_{\mathrm{T}}$ is defined as the threshold cycle number at which the amplified product is first detected. For the untreated control samples, $\Delta \Delta \mathrm{C}_{\mathrm{T}}$ equals 0 and $2^{0}$ equals 1 . An increased mRNA expression was defined as $n$-fold $\geq 2$ and a decreased expression was $n$-fold $\leq 0.5$ relative to the $24-\mathrm{h} \mathrm{N}$ expression level.

Statistical analyses. Changes in mRNA and protein expression relative to the 24-h normoxic value and between the samples exposed to hypoxia and hypoxia + reoxygenation of four to five individual experiments were analysed by means of the two-sided t-test. A p-value $\leq 0.05$ was considered to be statistically significant. Levels of significance between relative UPA, PAI-1 and UPAR protein levels and relative uPA, PAI-1 and UPAR mRNA expression were calculated by the bivariate Pearson correlation. A p-value $\leq 0.05$ (twotailed) was considered statistically significant. All the tests were analysed using the statistical package SPSS Release 12.0.1 for Windows (SPSS Inc., Chicago, Il., USA).

\section{Results}

Previous studies indicate that the proteolytic factors, uPA, PAI-1 and UPAR, in concert with tumour hypoxia, are key parameters influencing tumour invasion and metastasis. Little is known, however, about the impact of hypoxia and the subsequent reoxygenation on the expression of UPA, PAI-1 and uPAR in SCCHN. Therefore, the aim of the present study was to investigate the effects of short-, intermediate and longterm (up to $72 \mathrm{~h}$ ) hypoxia and subsequent reoxygenation on the mRNA and protein expression of the proteolytic factors, uPA, PAI-1 and uPAR, in head and neck tumour cell lines in comparison to a fibroblast control cell line.

Specific amplification and correlation of RNA concentration and $C_{T}$ values. Agarose gel electrophoresis (data not shown) revealed that each primer pair (Table I) amplified single bands of the predicted size for 28S rRNA (99 bp), uPA
(192 bp), PAI-1 (109 bp) and uPAR (164 bp). $\mathrm{C}_{\mathrm{T}}$ values and the log of RNA concentrations displayed a reverse linear correlation $\left(\mathrm{R}^{2}=0.992185\right.$ for $28 \mathrm{~S} ; \mathrm{R}^{2}=0.99077$ for PAI-1; $\mathrm{R}^{2}=0.990377$ for $\mathrm{uPA} ; \mathrm{R}^{2}=0.959814$ for $\mathrm{uPAR}$ ) as predicted (Fig. 1).

Relative expression of UPA $m R N A$ in the head and neck tumour cell lines, BHY, CAL27 and FaDu, and the fibroblast control cell line, VH7, exposed to hypoxia and subsequent reoxygenation. Cultivation of the tumour cell lines under normoxic conditions for up to $72 \mathrm{~h}$ lead to a significant increase in uPA mRNA levels compared to the 24-h base value (Fig. 2). Cells maintained in parallel under hypoxic conditions reacted differently regarding uPA mRNA expression, which also depended on the length of exposure. After $24 \mathrm{~h}$, a slight increase in uPA mRNA was observed in the FaDu and BHY cells whereas for CAL27 and the VH7 control cells a significant decline in mRNA expression was noted (Fig. 2). Reoxygenation of the once hypoxic cells for another $24 \mathrm{~h}$ lead to a major elevation in uPA mRNA expression in the VH7, BHY and CAL27 cells, as compared to their normoxic or hypoxic counterparts. In the cell lines, VH7, FaDu and CAL27, exposure to intermediate lengths of hypoxia $(48 \mathrm{~h})$ resulted in a significant reduction in uPA mRNA levels relative to the 24- and 48-h normoxic control. The subsequent 24-h reoxygenation period led to an increased uPA mRNA expression in all the cell lines. However, this was only significant for the cell lines, VH7 and BHY, in comparison to the 24-h normoxic control. Likewise, cells which were maintained under hypoxic conditions for up to $72 \mathrm{~h}$ followed by a $24-\mathrm{h}$ reoxygenation period also resumed uPA mRNA expression although the level of expression in the tumour cell lines was considerably reduced compared to the normoxic 72-h controls.

Relative expression of PAI-1 mRNA in the head and neck tumour cell lines BHY, CAL27 and FaDu, and the fibroblast control cell line VH7, exposed to hypoxia and subsequent reoxygenation. Cultivation of the cell lines FaDu and CAL27 


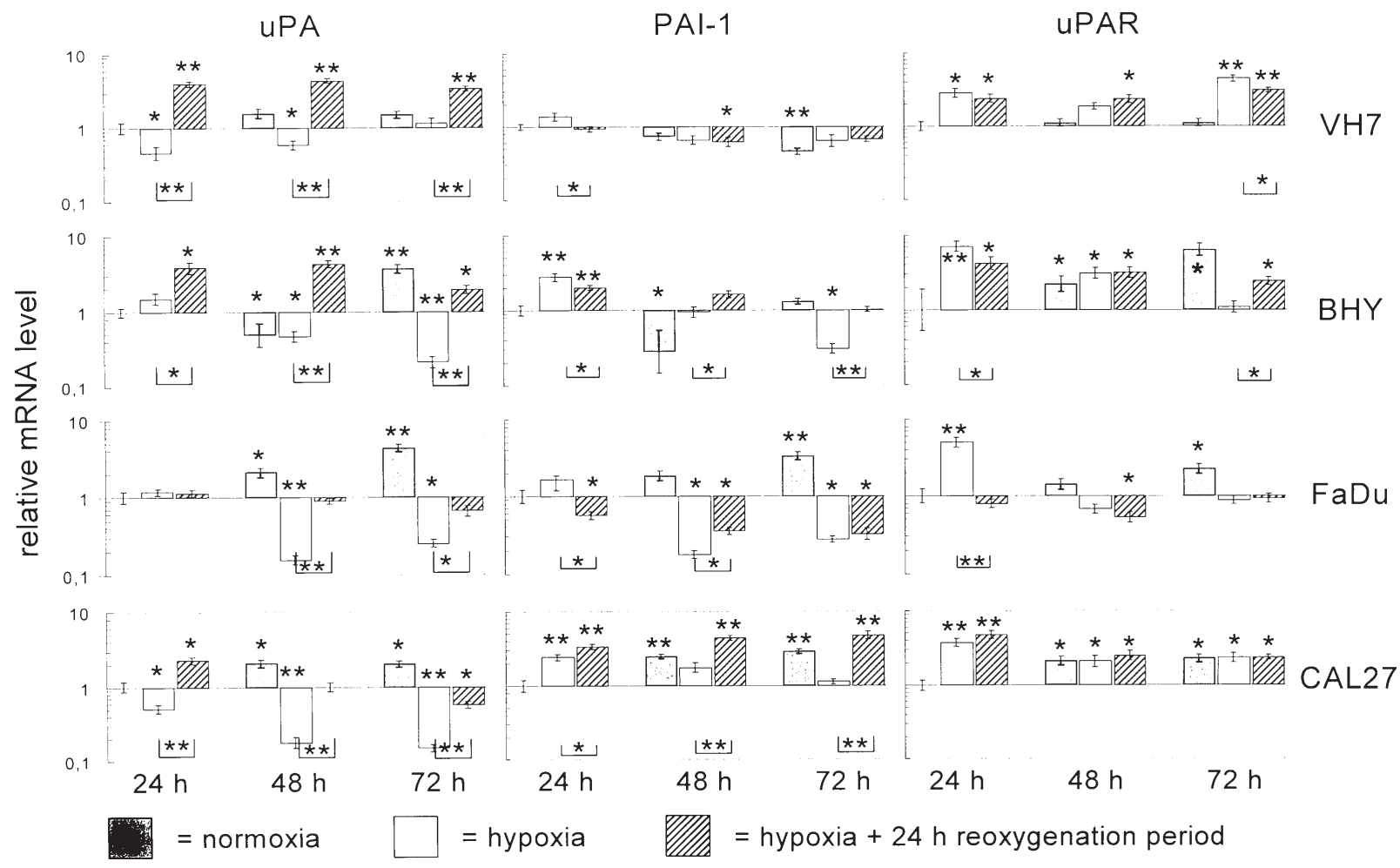

Figure 2. Time and oxygen-dependent changes of the urokinase-type plasminogen activator, plasminogen activator inhibitor type-1 and the urokinase-type plasminogen activator receptor mRNA levels for the cell lines, VH7, BHY, FaDu and CAL27. The changes in mRNA expression relative to the 24-h normoxic value and between the samples exposed to hypoxia and hypoxia + reoxygenation (I_ $\mid$ ) of four to five individual experiments were analysed by means of the two-sided t-test. A p-value $\leq 0.05$ was considered to be statistically significant $\left({ }^{*} \mathrm{p} \leq 0.05 ;{ }^{* *} \mathrm{p} \leq 0.01\right)$. Error bars indicate a $95 \%$ confidence interval.

under normoxic conditions for up to $72 \mathrm{~h}$ lead to a significant increase in PAI-1 mRNA levels compared to the 24-h base value. The VH7 control cells behaved differently; compared to the normoxic conditions, the PAI-1 mRNA expression significantly declined at the 72-h time-point (Fig. 2). Cells maintained in parallel under hypoxic conditions responded with an increased PAI-1 mRNA expression at the 24-h timepoint. Intermediate exposure to 48 -h hypoxia resulted in decreased PAI-1 mRNA levels compared to the 48-h normoxic control in the cell lines VH7, FaDu and CAL27. Prolonged hypoxic exposure for up to $72 \mathrm{~h}$, however, induced a considerable drop in PAI-1 mRNA expression in all the cell lines. Similar to the uPA mRNA expression, upon a 24-h reoxygenation period, PAI-1 mRNA levels changed compared to the normoxic or hypoxic mRNA expression values, being low for the tumour cell line, $\mathrm{FaDu}$, and the control cell line, VH7, progressively decreasing towards base line levels in the cell line BHY, and increasing in the CAL27 tumour cell line.

Relative expression of UPAR mRNA in the head and neck tumour cell lines, BHY, CAL27 and FaDu, and the fibroblast control cell line, VH7, exposed to hypoxia and subsequent reoxygenation. Cultivation of the four cell lines under normoxic conditions for up to $72 \mathrm{~h}$ lead to a moderate (VH7) or significant (BHY, FaDu, CAL27) increase in uPAR mRNA levels compared to the 24-h base-value. In consequence to the 24-h hypoxic exposure, uPAR mRNA levels markedly increased in the four cell lines. An increase relative to the normoxic control was still seen at 48-h hypoxic exposure in the cell lines, VH7, BHY and CAL27. This was different after $72 \mathrm{~h}$ of hypoxia. Whereas the control cell line, VH7, and the tumour cell line, CAL27, still expressed uPAR mRNA at high to moderate levels, a considerable drop in uPAR mRNA expression was observed for the BHY and FaDu tumour cell lines. Upon 24-, 48- and 72-h hypoxia with a subsequent reoxygenation period, the UPAR mRNA expression, with the exception of the FaDu cells, resumed and stayed above the normoxic control levels ( 24 and $48 \mathrm{~h}$ ) even at the extended exposure of $72 \mathrm{~h}$.

UPA, PAI-1 and UPAR protein content in BHY, FaDu, CAL27 and VH7 cells determined by ELISA. Cells were cultivated (see Materials and methods), the cell culture supernatants collected at the 24-, 48- and 72-h time-points and the adherent cells detached and harvested. Cells were lysed (see Materials and methods) and the uPA, PAI-1 and uPAR content was determined in the cell lysates and the cell culture supernatants. The data for the cell lysates and supernatants were pooled and plotted as the relative amounts determined for the 24-, 48- and 72-h time-points whereby the UPA, PAI-1 and UPAR protein expression levels under the 24-h normoxic conditions were set to 1 (Fig. 3).

The cell lines expressed different absolute amounts of UPA, PAI-1 and UPAR. With regard to the median total uPA concentration (cell lysate plus the supernatant related to the total protein content in the cellular detergent extract; 4 to 5 experiments, each measured in duplicate) at 24-h normoxia, the highest level of expression was determined in the CAL27 cells $(720 \mathrm{ng} / \mathrm{mg}$; range $630-1,130)$, followed by the BHY (472 ng/mg; range 387-472) and FaDu cells (314 ng/mg; 

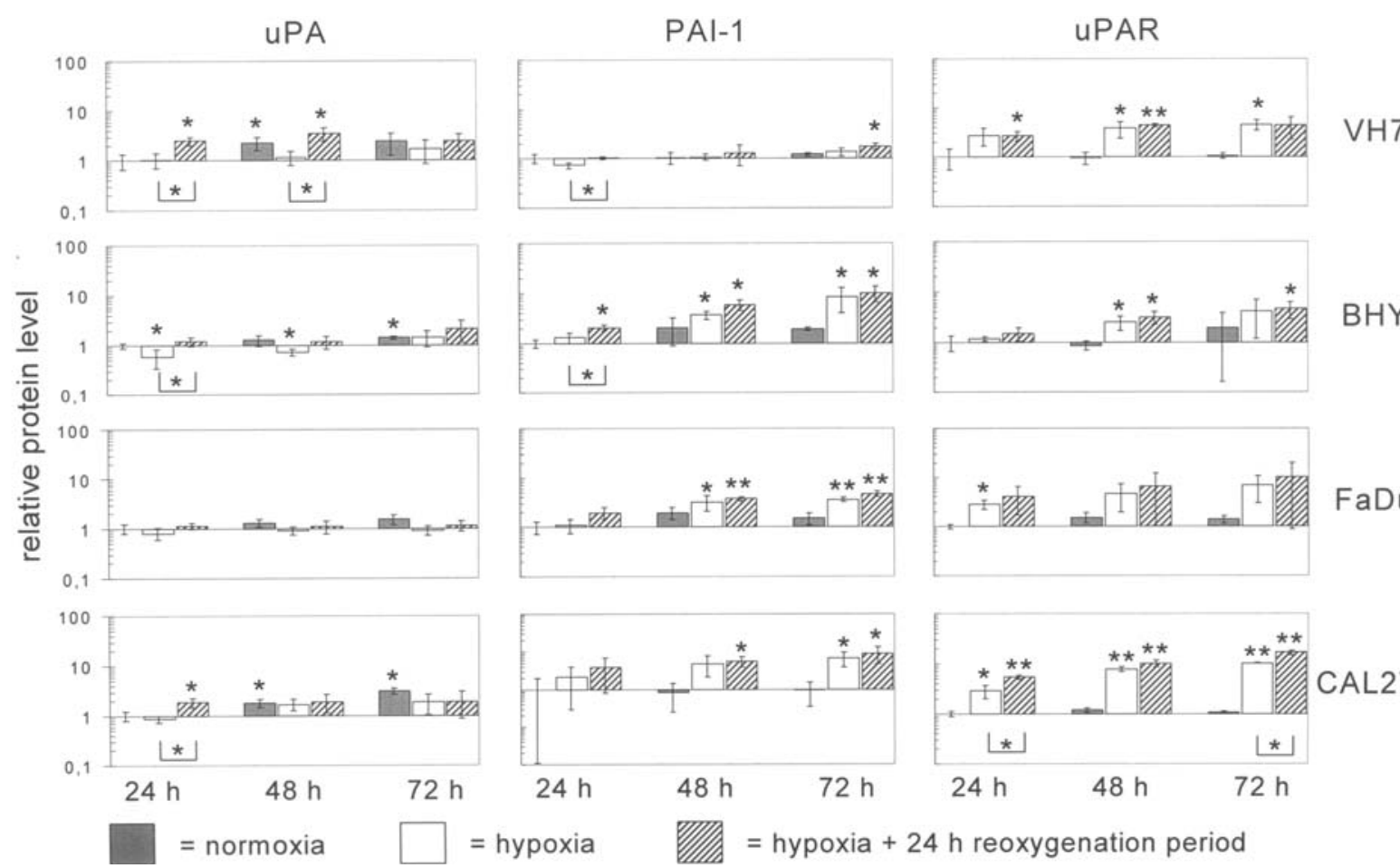

$\mathrm{BHY}$
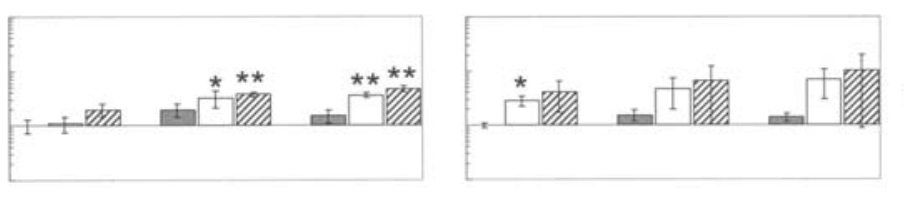

$\mathrm{FaDu}$
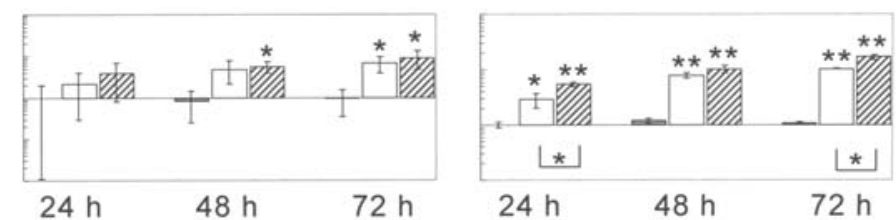

CAL27

Figure 3. Time and oxygen-dependent changes of cell-associated plus secreted protein levels of the urokinase-type plasminogen activator, plasminogen activator inhibitor type-1 and the urokinase-type plasminogen activator receptor for the cell lines, VH7, BHY, FaDu and CAL27. Changes in protein expression relative to the 24-h normoxic value and between the samples exposed to hypoxia and hypoxia + reoxygenation (I_l) of four to five individual experiments, ( $\mathrm{PPAR}, \mathrm{n}=3$ ), were analysed by means of the two-sided t-test. A p-value $\leq 0.05$ was considered to be statistically significant $\left({ }^{*} \mathrm{p} \leq 0.05 ;{ }^{* *} \mathrm{p} \leq 0.01\right.$ ). Error bars indicate standard deviation.

Table II. Correlation between mRNA and protein levels (cellassociated + secreted) of uPA, PAI-1 and UPAR in the head and neck tumour cell lines, BHY, FaDu, CAL27, and the control fibroblast cell line, VH7.

\begin{tabular}{llll}
\hline Cell line & \multicolumn{1}{c}{ uPA } & \multicolumn{1}{c}{ PAI-1 } & \multicolumn{1}{c}{ uPAR } \\
\hline VH7 & $\mathrm{r}=0.758^{\mathrm{b}}$ & $\mathrm{r}=0.369$ & $\mathrm{r}=0.774^{\mathrm{b}}$ \\
& $\mathrm{p}=0.000$ & $\mathrm{p}=0.058$ & $\mathrm{p}=0.000$ \\
BHY & $\mathrm{r}=0.194$ & $\mathrm{r}=-0.289$ & $\mathrm{r}=-0.142$ \\
& $\mathrm{n} . \mathrm{s}$. & $\mathrm{n} . \mathrm{s}$. & $\mathrm{n} . \mathrm{s}$. \\
FaDu & $\mathrm{r}=0.698^{\mathrm{b}}$ & $\mathrm{r}=-0.556^{\mathrm{b}}$ & $\mathrm{r}=-0.204$ \\
& $\mathrm{p}=0.000$ & $\mathrm{p}=0.003$ & $\mathrm{n} . \mathrm{s}$. \\
CAL27 & $\mathrm{r}=0.403^{\mathrm{a}}$ & $\mathrm{r}=0.448^{\mathrm{a}}$ & $\mathrm{r}=0.071$ \\
& $\mathrm{p}=0.037$ & $\mathrm{p}=0.019$ & $\mathrm{n} . \mathrm{s}$. \\
\hline
\end{tabular}

uPA, urokinase-type plasminogen activator; PAI-1, plasminogen activator inhibitor type-1; uPAR, urokinase-type plasminogen activator receptor. Pearson linear correlation analysis (two-sided) over all three time-points $(24,48$, and $72 \mathrm{~h})$ and oxygen treatment variants $(\mathrm{N}, \mathrm{H}, \mathrm{R})$ between relative UPA, PAI-1 and UPAR mRNA levels and relative uPA, PAI-1 and UPAR protein levels (cell-associated + secreted) was performed for the head and neck tumour cell lines and the fibroblast control cell line $\left({ }^{\mathrm{a}} \mathrm{p} \leq 0.05 ;{ }^{b} \mathrm{p} \leq 0.01\right)$ (n.s., no significance).

range 240-455) with the lowest values in the fibroblast control VH7 cells (6 ng/mg; range $4-8)$. The highest median total PAI-1 levels at 24-h normoxia were found in the fibroblast control VH7 cells $(21,836 \mathrm{ng} / \mathrm{mg}$; range 14,974-25,152), followed by the BHY cells $(4,500 \mathrm{ng} / \mathrm{mg}$; range 3,9096,374), the CAL27 (624 ng/mg; range 199-1,922) and FaDu cells (563 ng/mg; range 249-647). The median total uPAR content at 24-h normoxia was highest in the BHY cells (36 ng/mg; range 23-59), followed by the VH7 control cells (8 $\mathrm{ng} / \mathrm{mg}$; range 8-18), the CAL27 (7 ng/mg; range 7-8) and FaDu cells (3 ng/mg; range 3-20). Throughout the normoxic incubation period protein values remained at the same level or increased/ decreased slightly (Fig. 3).

Although ongoing exposure to hypoxia induced the significant downregulation of uPA mRNA in all the cell lines, protein levels, with the exception of the BHY cells, did not significantly alter but remained at steady state levels. On reoxygenation a tendency towards resuming protein production could be seen in the cell lines, VH7, BHY and CAL27. PAI-1 and UPAR protein expression levels, in contrast to the mRNA expression levels, generally increased under hypoxia, being the highest at 72-h exposure indicating the continuous production of the proteolytic factors over time, even under hypoxic conditions. This level of production was not affected by a subsequent 24 -h reoxygenation period.

Correlation between $m R N A$ and protein expression. We also calculated by means of Pearson's linear correlation coefficient $(r)$ if the observed changes in mRNA expression for uPA, PAI- 1 and UPAR over all three time points $(24,48$ and $72 \mathrm{~h}$ ) and all three oxygen treatment conditions (N, H, R) would correlate with the changes for total (cell-associated plus secreted) UPA, PAI-1 and UPAR protein expression (Table II). Between the uPA mRNA and protein expression, 
Table III. Correlation between mRNA and protein levels (cell-associated + secreted) of uPA, PAI-1 and uPAR in the head and neck tumour cell lines, BHY, FaDu, CAL27, and the control fibroblast cell line, VH7.

\begin{tabular}{|c|c|c|c|c|c|c|c|c|c|}
\hline \multirow[b]{2}{*}{ Cell line } & \multicolumn{3}{|c|}{ uPA } & \multicolumn{3}{|c|}{ PAI-1 } & \multicolumn{3}{|c|}{ uPAR } \\
\hline & $\mathrm{N}$ & $\mathrm{H}$ & $\mathrm{R}$ & $\mathrm{N}$ & $\mathrm{H}$ & $\mathrm{R}$ & $\mathrm{N}$ & $\mathrm{H}$ & $\mathrm{R}$ \\
\hline \multirow[t]{2}{*}{ VH7 } & $\mathrm{r}=0.907^{\mathrm{b}}$ & $\mathrm{r}=0.907^{\mathrm{a}}$ & $\mathrm{r}=0.907^{\mathrm{b}}$ & $\mathrm{r}=-0.200$ & $\mathrm{r}=-0.643$ & $\mathrm{r}=-0.151$ & $\mathrm{r}=0.866^{\mathrm{b}}$ & $\mathrm{r}=0.520$ & $\mathrm{r}=0.546$ \\
\hline & $\mathrm{p}=0.001$ & $\mathrm{p}=0.016$ & $\mathrm{p}=0.007$ & n.s. & $\mathrm{p}=0.067$ & n.s. & $\mathrm{p}=0.003$ & n.s. & n.s. \\
\hline \multirow[t]{2}{*}{ BHY } & $\mathrm{r}=0.498$ & $\mathrm{r}=-0.522$ & $\mathrm{r}=-0.555$ & $\mathrm{r}=-0.010$ & $\mathrm{r}=-0.697^{\mathrm{a}}$ & $\mathrm{r}=-0.755^{\mathrm{a}}$ & $\mathrm{r}=0.694^{\mathrm{a}}$ & $\mathrm{r}=-0.555$ & $\mathrm{r}=-0.459$ \\
\hline & n.s. & n.s. & n.s. & n.s. & $\mathrm{p}=0.037$ & $\mathrm{p}=0.019$ & $\mathrm{p}=0.038$ & n.s. & n.s. \\
\hline \multirow[t]{2}{*}{$\mathrm{FaDu}$} & $\mathrm{r}=0.748^{\mathrm{a}}$ & $\mathrm{r}=-0.180$ & $\mathrm{r}=0.361$ & $\mathrm{r}=0.429$ & $\mathrm{r}=-0.799^{\mathrm{b}}$ & $\mathrm{r}=-0.695^{\mathrm{a}}$ & $\mathrm{r}=0.566$ & $\mathrm{r}=-0.434$ & $\mathrm{r}=0.523$ \\
\hline & $\mathrm{p}=0.012$ & n.s. & n.s. & n.s. & $\mathrm{p}=0.010$ & $\mathrm{p}=0.038$ & n.s. & n.s. & n.s. \\
\hline \multirow[t]{2}{*}{ CAL27 } & $\mathrm{r}=0.733^{\mathrm{a}}$ & $r=-0.602$ & $\mathrm{r}=0.093$ & $\mathrm{r}=0.104$ & $\mathrm{r}=-0.434$ & $\mathrm{r}=0.879^{\mathrm{b}}$ & $\mathrm{r}=0.678^{\mathrm{a}}$ & $\mathrm{r}=-0.727^{\mathrm{b}}$ & $\mathrm{r}=-0.644$ \\
\hline & $\mathrm{p}=0.015$ & n.s. & n.s. & n.s. & n.s. & $\mathrm{p}=0.002$ & $\mathrm{p}=0.045$ & $\mathrm{p}=0.027$ & $\mathrm{p}=0.061$ \\
\hline
\end{tabular}

$\mathrm{N}$, normoxia; $\mathrm{H}$, hypoxia; $\mathrm{R}$, reoxygenation; uPA, urokinase-type plasminogen activator; PAI-1, plasminogen activator inhibitor type-1; uPAR, urokinase-type plasminogen activator receptor. Pearson linear correlation analysis (two-sided) between relative uPA, PAI- 1 and uPAR mRNA levels and relative uPA, PAI-1 and uPAR protein levels (cell-associated + secreted) according to oxygen treatment conditions over all three time-points was performed for the head and neck tumour cell lines and the fibroblast control cell line $\left({ }^{\mathrm{a}} \mathrm{p} \leq 0.05\right.$; $\left.{ }^{\mathrm{b}} \mathrm{p} \leq 0.01\right)(\mathrm{n} . \mathrm{s}$., no significance).

the cell lines, VH7, FaDu and CAL27, showed a statistically strong, moderate and weak significant positive correlation, respectively. For PAI-1, correlation analysis revealed statistically relevant correlations for the tumour cell lines, FaDu (moderate, negative correlation) and CAL27 (weak, positive correlation). With regard to uPAR, only the control cell line, VH7, displayed a statistically significant (strong, positive) correlation between uPAR mRNA and protein levels. We next compared the correlation between changes in protein and mRNA expression according to oxygen treatment conditions over all three time points (Table III). The three cell lines, VH7, FaDu and CAL27, showed a statistically significant positive correlation between normoxic uPA mRNA and protein expression. Under hypoxic and reoxygenating conditions, only the control cell line, VH7, displayed a high, statistically significant, positive correlation between the uPA mRNA and protein. For PAI-1, correlation analysis revealed a statistically significant negative correlation for the cell lines, BHY and FaDu, under hypoxic and reoxygenating conditions, and a high, statistically significant positive correlation for the cell line, CAL27, under reoxygenating conditions. No correlation was seen under normoxic conditions. With regard to UPAR, under normoxic conditions the cell lines, VH7, BHY and CAL27, showed a statistically significant positive correlation between the UPAR mRNA and protein. Under hypoxic conditions, only the cell line, CAL27, displayed a statistically significant negative correlation. No statistically significant correlations for UPAR were observed for any cell line under reoxygenating conditions.

\section{Discussion}

Many studies using different cell and animal tumour models indicate that tumour hypoxia is a key parameter influencing malignant progression in head and neck cancer. However, little is known about the impact of reoxygenation in SCCHN under therapy (4). Using a real-time semiquantitative RTPCR method, we analysed the influence of hypoxia $(<0.5 \%$ $\mathrm{O}_{2}$, up to $72 \mathrm{~h}$ ) and the subsequent 24-h reoxygenation period on three components of the plasminogen activation system (uPA, PAI-1, uPAR), in three different cell lines derived from human SCCHN and a fibroblast control cell line. These three components are known to be associated with poor outcome in patients afflicted with various types of cancer $(21,24,25)$.

In all cell lines examined, we saw significant oxygen- and time-dependent changes in UPA, PAI-1 and UPAR mRNA levels. Regarding the uPA mRNA expression, our findings are in agreement with data described in the literature showing that hypoxia leads to a reduction in uPA mRNA expression. For instance, it has been reported that in murine lung tissue, uPA mRNA expression decreases significantly after hypoxic exposure (15), or remains at steady state levels in human vascular endothelial cells (16). In our cell lines tested, reoxygenation triggered the upregulation of the uPA mRNA expression after hypoxia. To our knowledge, no study has yet described the effects of reoxygenation on uPA mRNA synthesis in vitro. However, indirect evidence is given in a study by Mahabeleshwar and Kundu (28) revealing that the reoxygenation of human breast cancer cells can stimulate $\mathrm{NF}-\kappa \mathrm{B}$-dependent uPA promoter activity and ultimately lead to increased uPA synthesis and secretion.

With regard to changes in the PAI- 1 mRNA levels in our cell lines tested under hypoxia, the most significant rise occurred after 24-h exposure to hypoxia which is in accordance with published data $(11,12,15,30)$. Remarkably, the increase in PAI-1 mRNA levels seen in these earlier studies was not affected by the oxygen concentration during hypoxic exposure, 
which in these studies ranged from 1 to $8 \%$. Furthermore, all of these studies only tested hypoxic periods ranging from 2 to $24 \mathrm{~h}$. In our study, however, a longer time of exposure of up to $72 \mathrm{~h}$ under hypoxic conditions of below $0.5 \%$ oxygen, compared to the 24-h data, resulted in a considerable drop in PAI-1 mRNA expression. Similar observations have been made by Wang and Kurpakus-Wheater (13) after exposing corneal epithelial cells for 3 days to low oxygen concentrations. They observed a $37 \%$ drop in PAI-1 mRNA levels compared to the normoxic control. Few investigations have studied the effects of reoxygenation on PAI-1 mRNA expression and they all describe declining PAI-1 mRNA levels after reoxygenation $(30,31)$. Although these data are in accordance with some of our findings, the effect of hypoxia and reoxygenation on PAI-1 mRNA expression was different in the tumour cell lines, CAL27 and BHY. Long-term (72-h) exposure to hypoxia plus reoxygenation restored the normoxic conditions at $72 \mathrm{~h}$ or reached base-line levels, respectively. This was not the case for the other two cell lines. When exposed to long-term hypoxia, these cells were impaired by the low-oxygen treatment regarding PAI-1 mRNA expression and therefore did not resume PAI-1 mRNA expression, even after re-exposure to normoxic conditions.

In line with our data, augmented uPAR mRNA levels have been observed by others in human microvascular endothelial (16) and breast cancer cells $(19,29)$ after hypoxic exposure. A possible explanation for the strong rise in UPAR mRNA during hypoxia has been supplied by the experiments of Maity and Solomon (19). They observed increased UPAR mRNA stability in breast carcinoma cells exposed to extreme hypoxia $\left(0.2 \% \mathrm{O}_{2}\right)$ which rapidly decreased after reoxygenation. However, upon reoxygenation, with few exceptions, we generally observed only marginal changes relative to the hypoxic situation, indicating decelerated uPAR mRNA degradation.

Different pathways are responsible for the activation of transcription after hypoxia. During hypoxia, mitochondria cannot carry out oxidative phosphorylation pathways, and electron carriers which would normally be oxidised are reduced. These reduced carriers can react directly with any existing oxygen and generate free radicals which in turn can activate transcription factors, such as HIF-1, AP-1 and NF-кB (32). Recent in vitro and in vivo studies $(33,34)$ have shown that the reoxygenation of hypoxic tumour cells can also result in free radical formation, leading to the nuclear accumulation of Hypoxia-Inducible Factor-1 (HIF-1), a major oxygen homeostasis regulator. During normoxia, this heterodimeric transcription factor is rapidly degraded by the proteasome (34). Hypoxia, however, stabilises its hypoxiaregulated subunit, HIF- $1 \alpha$, thus enabling the dimerisation with its oxygen-independent subunit, HIF-1ß, to form the active HIF-1 transcription complex. This complex can then bind to hypoxia-regulatory-elements (HRE) in the nucleus, resulting in the transcription or transactivation of genes, such as PAI-1, uPA and uPAR $(20,35,36)$. This notion is supported by certain studies showing that the stabilisation of HIF- $1 \alpha$ is responsible for the hypoxia-mediated increased PAI-1 expression in human keloid fibroblasts and lung cancer cells $(37,38)$. The increase in UPA, uPAR and PAI-1 mRNA levels upon reoxygenation could therefore be caused by the nuclear accumulation of the HIF-1 complex in response to reactive oxygen during reoxygenation.

We also correlated uPA, PAI-1 and uPAR mRNA expression levels with the protein levels of these proteolytic factors determined by commercially available ELISAs and found no uniform correlation pattern. Although in agreement with the results obtained for the SCCHN cell lines, FaDu and CAL27, our findings with the SCCHN cell line, BHY, contrast with the results from a study by Spyratos et al. This study employed real-time quantitative PCR and ELISA measurements in order to determine uPA and PAI-1 mRNA and antigen content in breast cancer tumour specimens and found that mRNA expression data correlated with those obtained by ELISA (39). In contrast, a study correlating PAI-1 mRNA levels obtained by means of real-time RT PCR with PAI-1 antigen levels in endometrial tissue samples, only found a significant correlation in healthy tissue samples, and no correlation in ovarian endometriosis samples (40).

In our study, both hypoxia and reoxygenation induced statistically significant changes in mRNA and protein levels in the various cell lines investigated, showing that oxygen tension is a strong modulator of the plasminogen activation system in vitro. Additionally, various regulatory elements in the mRNAs of the components of the plasminogen activation system, such as AU-rich elements (ARE) and mRNA binding proteins, indicate that the post-transcriptional regulation of gene expression, which could lead to a higher translation efficiency, plays an important role in this system (41). As we found no uniform correlation pattern between mRNA and protein levels, we believe that in the clinical situation the determination of protein content in tumour samples is of higher diagnostic value than the determination of mRNA, since mRNA represents only a snap-shot at a particular timepoint, in contrast to the final effector protein.

Oxygen tension could be a modulator of the fragile balance between the various components of the plasminogen activation system. In a solid tumour this could have various consequences: A shift towards uPA could trigger a proteolytic cascade resulting in increased tumour matrix disruption and unfavourable conditions for neovascularization (42). Increased proteolytic activity can induce autoproteolysis of plasmin and lead to the formation of angiostatin resulting in the inhibition of vascular endothelial cell proliferation and induction of endothelial cell apoptosis (43). Furthermore, a shift of balance towards PAI- 1 can result in facilitated tumour cell dissemination to other organ sites since PAI-1 regulates cell adhesion and the detachment of cells from the extracellular matrix (ECM) by binding to the ECM-protein, vitronectin (44). Moreover, due to its capacity to inhibit apoptosis both in transformed and non-transformed cells (45), its ability to modify tumour angiogenesis in a concentration-dependent manner (46), and its influence on signal transduction and cell proliferation upon internalisation with its complexing partners, uPA and uPAR (9), PAI-1 can increase the aggressiveness of a tumour. In addition, in vitro studies have shown that the invasive capacity of tumour cells is strongly dependent on a critical balance between uPA and its inhibitor, PAI-1 (47). This highly complex interaction between the plasminogen activation system and oxygen tension could therefore explain in part why certain reoxygenated subgroups 
of SCCHN tumours are associated with poor treatment outcome.

\section{Acknowledgements}

We are very grateful for the expert assistance of Ms. G. Echle with the PCR assays. Mrs. A. Sturmheit and Mrs. C. Schnelldorfer are thanked for the excellent technical assistance with the uPA, uPAR, and PAI-1 ELISA measurements. The authors thank Dr M. J. Sprague for very helpful and valuable discussion and critical reading of the manuscript. Professor P. Boucamp, Heidelberg, is thanked for providing the VH7 cells. This study was supported in part by a grant from Dr Mildred-Scheel-Stiftung to LDS (Deutsche Krebshilfe; Sp No. 10-1977).

\section{References}

1. Brizel DM, Sibley GS, Prosnitz LR, Scher RL and Dewhirst MW: Tumour hypoxia adversely affects the prognosis of carcinoma of the head and neck. Int J Radiat Oncol Biol Phys 38: 285-289, 1997

2. Le QT, Denko NC and Giaccia AJ: Hypoxic gene expression and metastasis. Cancer Metastasis Rev 23: 293-310, 2004.

3. Harrison LB, Chadha M, Hill RJ and Hu Kand Shasha D: Impact of tumour hypoxia and anemia on radiation therapy outcomes. Oncologist 7: 492-508, 2002.

4. Dietz A, Vanselow B, Rudat V, Conradt C, Weidauer H, Kallinowski F and Dollner R: Prognostic impact of reoxygenation in advanced cancer of the head and neck during the initial course of chemoradiation or radiotherapy alone. Head Neck 25: 50-58, 2003.

5. Andreasen PA, Kjoller L, Christensen L and Duffy MJ: The urokinase-type plasminogen activator system in cancer metastasis (Review): Int J Cancer 72: 1-22, 1997.

6. Fitzpatrick TE and Graham CH: Stimulation of plasminogen activator inhibitor type-1 expression in immortalized human trophoblast cells cultured under low levels of oxygen. Exp Cell Res 245: 155-162.

7. Duffy MJ: The urokinase plasminogen activator system: role in malignancy. Curr Pharm Des 10: 39-49, 2004.

8. Loskutoff DJ, van Mourik JA, Erickson LA and Lawrence D: Detection of an unusually stable fibrinolytic inhibitor produced by bovine endothelial cells. Proc Natl Acad Sci USA 80: 2956-2960, 1983

9. Harbeck N, Krüger A, Sinz S, Kates RE, Thomssen C, Schmitt M and Jänicke F: Clinical relevance of the plasminogen activator inhibitor type 1- a multifaceted proteolytic factor. Onkologie 24: 238-244, 2001.

10. Schmitt M, Harbeck N, Thomssen C, Wilhelm O, Magdolen V, Reuning U, Ulm K, Höfler H, Jänicke F and Graeff H: Clinical impact of the plasminogen activation system in tumour invasion and metastasis: prognostic relevance and target for therapy. Thromb Haemost 78: 285-296, 1997.

11. Uchiyama T, Kurabayashi M, Ohyama Y Utsugi T, Akuzawa N, Sato M, Tomono S, Kawazu S and Nagai R: Hypoxia induces transcription of the plasminogen activator inhibitor type-1 gene through genistein-sensitive tyrosine kinase pathways in vascular endothelial cells. Arterioscler Thromb Vasc Biol 20: 1155-1161, 2000.

12. Fink T, Ebbesen P and Zachar V: Quantitative gene expression profiles of human liver-derived cell lines exposed to moderate hypoxia. Cell Physiol Biochem 11: 105-114, 2001

13. Wang Z and Kurpakus-Wheater M: Decreased plasminogen activator inhibitor type-1 secretion in hypoxic corneal epithelial cells is associated with increased urokinase plasminogen activator activity. Int J Biochem Cell Biol 35: 339-348, 2003.

14. Ito T, Takenaka K, Sakai H, Yoshimura S, Hayashi K, Noda S and Sakai N: Elevation of mRNA levels of tissue-type plasminogen activator and urokinase-type plasminogen activator in hippocampus and cerebral cortex following middle cerebral artery occlusion in rats. Neurol Res 22: 413-419, 2000.

15. Pinsky DJ, Liao H, Lawson CA, Yan SF, Chen J, Carmeliet P, Loskutoff DJ and Stern DM: Coordinated induction of plasminogen activator inhibitor-1 (PAI-1) and inhibition of plasminogen activator gene expression by hypoxia promotes pulmonary vascular fibrin deposition. J Clin Invest 102: 919-928, 1998.
16. Kroon ME, Koolwijk P, van der Vecht B and van Hinsbergh VW Urokinase receptor expression on human microvascular endothelial cells is increased by hypoxia: implications for capillarylike tube formation in a fibrin matrix. Blood 96: 2775-2783, 2000.

17. Trisciuoglio D, Iervolino A, Candiloro A, Fibbi G, Fanciulli M, Zangemeister-Wittke U, Zupi G and del Bufalo D: bcl-2 induction of urokinase plasminogen activator receptor expression in human cancer cells through Sp1 activation: involvement of ERK1/ERK2 activity. J Biol Chem 20: 6737-6745, 2004.

18. Rofstad EK, Rasmussen H, Galappathi K, Mathiesen B, Nilsen K and Graff BA: Hypoxia promotes lymph node metastasis in human melanoma xenografts by up-regulating the urokinasetype plasminogen activator receptor. Cancer Res 62: 1847-1853, 2002 .

19. Maity A and Solomon D: Both increased stability and transcription contribute to the induction of the urokinase plasminogen activator receptor (uPAR) message by hypoxia. Exp Cell Res 15: 250-257, 2000.

20. Graham CH, Fitzpatrick TE and McCrae KR: Hypoxia stimulates urokinase receptor expression through a heme protein-dependent pathway. Blood 91: 3300-3307, 1998.

21. Foekens JA, Peters HA, Look MP, Portengen H, Schmitt M, Kramer MD, Brünner N, Jänicke F, Meijer-van Gelder ME, Henzen-Logmans SC, van Putten WL and Klijn JG: The urokinase system of plasminogen activation and prognosis in 2780 breast cancer patients. Cancer Res 60: 636-643, 2000.

22. Kaneko T, Konno H, Baba M, Tanaka T and Nakamura S: Urokinase-type plasminogen activator expression correlates with tumour angiogenesis and poor outcome in gastric cancer. Cancer Sci 94: 43-49, 2003.

23. Cantero D, Friess H, Deflorin J, Zimmermann A, Brundler MA, Riesle E, Korc M and Buchler MW: Enhanced expression of urokinase plasminogen activator and its receptor in pancreatic carcinoma. Br J Cancer 75: 388-395, 1997.

24. Pedersen H, Brünner N, Francis D, Osterlind K, Ronne E, Hansen HH, Dano K, and Grondahl-Hansen J: Prognostic impact of urokinase urokinase receptor and type 1 plasminogen activator inhibitor in squamous and large cell lung cancer tissue. Cancer Res 54: 4671-4675, 1994.

25. Hundsdorfer B, Zeilhofer HF, Bock KP, Dettmar P, Schmitt M, Kolk A, Pautke C and Horch HH: Tumour-associated urokinase-type plasminogen activator (uPA) and its inhibitor PAI-1 in normal and neoplastic tissues of patients with squamous cell cancer of the oral cavity - clinical relevance and prognostic value. J Craniomaxillofac Surg 33: 191-196, 2005.

26. Jänicke F, Schmitt M, Pache L, Ulm K, Harbeck N, Höfler H and Graeff $\mathrm{H}$ : Urokinase (uPA) and its inhibitor PAI-1 are strong and independent prognostic factors in node-negative breast cancer. Breast Cancer Res Treat 24: 195-208, 1993.

27. Livak KJ and Schmittgen TD: Analysis of relative gene expression data using real-time quantitative PCR and the 2(-Delta Delta C(T)) method. Methods 25: 402-408, 2001

28. Mahabeleshwar GH and Kundu GC: Tyrosine kinase p561ck regulates cell motility and nuclear factor kappa B-mediated secretion of urokinase type plasminogen activator through tyrosine phosphorylation of nuclear factor kappa B following hypoxia/reoxygenation J Biol Chem 26: 52598-52612, 2003.

29. Graham CH, Forsdike J, Fitzgerald CJ and MacdonaldGoodfellow S: Hypoxia-mediated stimulation of carcinoma cell invasiveness via upregulation of urokinase receptor expression. Int J Cancer 80: 617-623, 1999.

30. Koong AC, Denko NC, Hudson KM, Schindler C, Swiersz L, Koch C, Evans S, Ibrahim H, Le QT, Terris DJ and Giaccia AJ: Candidate genes for the hypoxic tumour phenotype. Cancer Res 15: 883-887, 2000.

31. Shatos MA, Doherty JM, Stump DC, Thompson EA and Collen D: Oxygen radicals generated during anoxia followed by reoxygenation reduce the synthesis of tissue-type plasminogen activator and plasminogen activator inhibitor-1 in human endothelial cell culture. J Biol Chem 25: 20443-20448, 1990.

32. Shih SC and Claffey KP: Hypoxia-mediated regulation of gene expression in mammalian cells. Int J Exp Pathol 79: 347-357, 1998

33. Chandel NS, Maltepe E, Goldwasser E, Mathieu CE, Simon MC and Schumacker PT: Mitochondrial reactive oxygen species trigger hypoxia-induced transcription. Proc Natl Acad Sci USA 29: 11715-11720, 1998

34. Moeller BJ, Cao Y, Li CY and Dewhirst MW: Radiation activates HIF-1 to regulate vascular radiosensitivity in tumours: role of reoxygenation free radicals and stress granules. Cancer Cell 5: 429-441, 2004. 
35. Tacchini L, Matteucci E, De Ponti C and Desiderio MA: Hepatocyte growth factor signaling regulates transactivation of genes belonging to the plasminogen activation system via hypoxia inducible factor-1. Exp Cell Res 1: 391-401, 2003.

36. Krishnamachary B, Berg-Dixon S, Kelly B, Agani F, Feldser D, Ferreira G, Iyer N, LaRusch J, Pak B, Taghavi P and Semenza GL: Regulation of colon carcinoma cell invasion by hypoxiainducible factor 1. Cancer Res 1: 1138-1143, 2003.

37. Zhang Q, Wu Y, Chau CH, Ann DK, Bertolami CN and Le AD: Crosstalk of hypoxia-mediated signaling pathways in upregulating plasminogen activator inhibitor- 1 expression in keloid fibroblasts. J Cell Physiol 199: 89-97, 2004.

38. Kimura D, Imaizumi T, Tamo W, Sakai T, Ito K, Hatanaka R, Yoshida H, Tsushima T, Satoh K and Fukuda I: Hypoxia enhances the expression of plasminogen activator inhibitor-1 in human lung cancer cells EBC-1. Tohoku J Exp Med 196: 259-267, 2002.

39. Spyratos F, Bouchet C, Tozlu S, Labroquere M, Vignaud S, Becette V, Lidereau R and Bieche I: Prognostic value of uPA, PAI-1 and PAI-2 mRNA expression in primary breast cancer. Anticancer Res 22: 2997-3003, 2002.

40. Ramon L, Gilabert-Estelles J, Castello R, Gilabert J, Espana F, Romeu A, Chirivella M, Aznar J and Estelles A: mRNA analysis of several components of the plasminogen activator and matrix metalloproteinase systems in endometriosis using a real-time quantitative RT-PCR assay. Hum Reprod 20: 272-278, 2005.
41. Montuori N, Rossi G and Ragno P: Post-transcriptional regulation of gene expression in the plasminogen activation system. Biol Chem 383: 47-53, 2002.

42. Merchan JR, Tang J, Hu G, Lin Y, Mutter W, Tong C, Karumanchi SA, Russell SJ and Sukhatme VP: Protease activity of urokinase and tumour progression in a syngeneic mammary cancer model. J Natl Cancer Inst 98: 756-764, 2006.

43. Wang H, Doll JA, Jiang K, Cundiff DL, Czarnecki JS, Wilson M, Ridge KM and Soff GA: Differential binding of plasminogen plasmin and angiostatin 45 to cell surface beta-actin: implications for cancer-mediated angiogenesis. Cancer Res 66: 7211-7215, 2006.

44. Déry MA, Michaud MD and Richard DE: Hypoxia-inducible factor 1: regulation by hypoxic and non-hypoxic activators. Int $\mathrm{J}$ Biochem Cell Biol 37: 535-540, 2005.

45. Kwaan HC, Wang J, Svoboda K and Declerck PJ: Plasminogen activator inhibitor 1 may promote tumour growth through inhibition of apoptosis. Br J Cancer 82: 1702-1708, 2000.

46. Devy L, Blacher S, Grignet-Debrus C, Bajou K, Masson V, Gerard RD, Gils A, Carmeliet G, Carmeliet P, Declerck PJ, Noel A and Foidart JM: The pro- or antiangiogenic effect of plasminogen activator inhibitor 1 is dose dependent. FASEB J 16: 147-154, 2002.

47. Liu G, Shuman MA and Cohen RL: Co-expression of urokinase, urokinase receptor and PAI- 1 is necessary for optimum invasiveness of cultured lung cancer cells. Int J Cancer 60: 501-506, 1995. 